\title{
Unbridled liberalism and a pandemic: at a crossroads between techno authoritarianism and \\ a new social order
}

\author{
Giovanni Dosi
}

\section{Abstract}

This paper analyses some of the trends in global capitalism prior to the pandemic and some specificities of the latter that are likely to place the global economy at a crossroads between maintaining the prevailing trend of techno authoritarianism in the governance of countries and a change in the social order. It describes the arrival of the pandemic amid increasing technologization and a fragile socioeconomic architecture, which has been deteriorating since the emergence of neoliberalism in the 1980s and, especially, since the 2008-2009 financial crisis. The major trends analysed are: globalization and the rise of China, wage stagnation and the gap between productivity and wages, along with the explosion in the rate of profit, in addition to (financial and non-financial) corporate profits and the convergence of artificial intelligence and automation. It also outlines a number of lessons to be learned from the pandemic.

\section{Keywords}

COVID-19, virus, epidemics, economic aspects, social aspects, social structure, economic conditions, liberalism, health, health policy, employment, employment policy, working hours, economic policy, social policy

JEL classification

D33, F60, O33, P11

\section{Author}

Giovanni Dosi is a Professor at the Institute of Economics at the Scuola Superiore Sant'Anna in Pisa, Italy. Email: giovanni.dosi@santannapisa.it. 


\section{Introduction}

This paper will begin by setting out some observations - both general and specific - about the recent COVID-19 pandemic and the official responses to it. ${ }^{1}$

First, the COVID-19 novel coronavirus disease emerged in a Western society characterized by the fragility of its social architecture and its economic and technological structure. At the same time, China has become "the factory of the world" and is gaining increasing weight within global technological and political leadership.

Second, the socioeconomic structure that sustained the "glorious years" of post-war capitalism had already deteriorated for endogenous reasons by the 1970s and was devastated by the conjunction between the rise of fanatic liberalism (Reagan and Thatcher) and the fall of the Soviet Union (which, for all the citizens of the world outside its orbit, represented a miraculous shield against the rapacity of the capitalists).

Third, the 2008 crisis, which immediately turned from a financial crash into a recession in the real economy, was responded to at best (as in the United States) by an attempt to return to a situation of "normality" through Keynesian fiscal policies and (anti-)redistributive policies aimed at socializing financial losses. In the worst case (Europe), the masochistic austerity policies adopted led only to anaemic growth in the stronger countries and persistent stagnation in the others.

And then came the COVID-19 pandemic, which was at first widely underestimated before exploding amidst collective panic. This formed a short-circuit with the incompetence of most political classes which, especially in the presence of disastrous health systems, resorted to the simplest and crudest response, extremely painful in social terms and not very effective from a long-term epidemiological point of view: lockdowns and army patrols on the streets instead of mass testing and early treatment.

Before delving deeper into those issues, however, the pre-existing economic and social trends should be examined.

\section{Ongoing trends ${ }^{2}$}

\section{Globalization and the rise of China as the "factory of the world"}

After 40 years of international political pressure towards "free trade", the liberalization of capital movements has been one of the main causes of the economic instability of the last 20 years (Stiglitz, 2002).

At the same time, far-reaching and rapid changes in the international division of labour with the emergence of China as the world's industrial hub have significantly reduced the strength of the working classes in the developed West and, in particular, their bargaining power.

\section{Wage stagnation and a widening gap between productivity growth and wage growth}

Differences from one country to the next notwithstanding, from the 1980s onwards average wages (especially in the lower brackets) began to grow more slowly than productivity in almost all countries. As a result, the share of wages in gross domestic product (GDP) also fell.

\footnotetext{
1 Most of these issues are discussed in more detail in Dosi (1984) and Freeman and Soete (1994) and, more recently, in Dosi and Virgillito (2019, 2020a and 2020b), Dosi and others (2020) and Bellomo and others (2020).

2 For more details, see Dosi and Virgillito (2019), on which this section is largely based.
} 


\section{The explosion of profits, especially financial earnings}

This is the obvious corollary to the previous point. The statistical data even underestimate the phenomenon because the remunerations of top management are traditionally included among "wages and salaries" when, clearly, the dynamics of what senior executives are paid in no way correlate to the wages earned by their production-line workers. In addition, the share of financial earnings has increased disproportionately.

\section{The explosion of financial and non-financial income}

The "financialization" of economies certainly includes financial income in the strictest sense: names such as Goldman Sachs, J.P. Morgan and Morgan Stanley are known to all. Less well known are the hundreds of private equity funds that, as a famous prime minister would have it, speculate like locusts on acquisitions and divestitures of companies in the real economy, regardless of the damage to the economy in the long term.

But these rents go far beyond that.

Think of the income derived from patents - primarily, pharmaceutical patents (see below) - and then, more generally, income derived from the expansion of market-based organizational models into spheres that were previously, in Europe at least, almost exclusively public: education, research and health are the obvious examples.

Finally, mention should also be made of the "information-based" revenues of such giant oligopolies as Google, Facebook, Amazon and others.

\section{Technological convergence between artificial intelligence and automation (the latest trend)}

It is only just beginning, but this process promises to radically change working conditions in "factories" and "offices", significantly increase the role of what are known as platforms, heighten the polarization of working conditions and wages among workers and drastically reduce their bargaining power.

\section{The sudden arrival of COVID-19}

It was against the backdrop of those longer-term trends that the pandemic hit. Here too, some background information is necessary. Certainly, COVID-19 is not at all an ordinary flu, but neither is it the Black Death of the fourteenth century. Although the world is facing an unprecedented health crisis, the COVID-19 pandemic is not, in terms of absolute or relative mortality, among the worst ever, especially thanks to the availability of better medical care than in the past. The Spanish flu of 1919 resulted in a mortality rate of $2.73 \%$, but the Black Death of the fourteenth century, which was by far the worst, wiped out more than $40 \%$ of the European population.

Unlike the latter, the direct economic impact of the current pandemic has been more limited.

The medieval plague had a great economic impact and was essentially egalitarian: the reduction of almost a third in the labour supply fuelled a surge in wages, while the death of direct heirs led to a massive drop in the price of land.

Today, the main impact of this pandemic is on account of the containment and suppression measures adopted and their interactions with pre-existing economic and social inequalities. The former tend to amplify the latter. 
Thus, in many countries - including those with universal public health systems, albeit impoverished by decades of ferocious cuts, such as Italy, France and the United Kingdom - even the location of the patient's home often influences access to hospital care.

The deepest tragedy, however, is to be seen in countries where health care is predominantly a private concern, such as the United States, where income and skin colour are excellent predictors of the likelihood of surviving the virus or succumbing to it.

And then come the effects of lockdowns on present and future earnings, on the probability of dismissals, on the possibility of working remotely...

All this is even more pronounced for workers in the informal economy - which, it should be noted, accounts for as much as $50 \%$ of jobs in southern Italy and surely more in developing countries - and for irregular immigrants.

Staying at home appears to be an exclusive privilege of those who work in companies or public agencies that are prepared for teleworking (more the exception than the rule) and for those who have some accumulated savings and therefore can afford not to work. But what about all the others? At best, compulsory vacations and parental leave paid at 50\%; in the worst case, significant reductions in job earnings and, in many cases, part-time and precarious work.

One of the many bitter lessons that the pandemic is teaching us is how the difference in labour rights between public employees, private-sector employees, the self-employed and own-account workers becomes unmanageable and even less tolerable during a health emergency. The manufacturing sector strikes of recent months in Italy were clearly motivated by the incomprehensible lack of safety protection measures: for example, reduced shift sizes to ensure distance between workers. Working less but everyone working (spread over several shifts with fewer people) for the same wages could be, and still is, a solution that would ensure output, earnings and employment, but no initiative has been taken in that direction. Orders to avoid crowds have proliferated, but no one says anything about the responsibility of companies to ensure safe conditions with protective equipment.

Then, the economic inequalities are compounded by social and territorial inequalities.

Can online education make up for school closures? Unfortunately, virtual schools cannot be set up in ten days, large sectors of the population lack Internet connections and the necessary devices, and the programmes are far from structured. In any event, it will never compare to face-to-face education, unless the aim is to train a society of subjects with very different and polarized skills, which would also imply polarized "opportunities". Distance learning is also a source of wide gaps in learning between students of different socioeconomic origins and increases the risk of isolation of students who belong to marginalized groups.

Obviously there is no shortage of anecdotes about (almost) successful experiments - perhaps at schools and colleges in the wealthiest neighbourhoods - but we should also be concerned and ask ourselves whether distance education works for students in poorer and more marginalized neighbourhoods, which tend to have very low school attendance rates.

In classrooms already affected by widespread poverty and social gaps, school - as an institution as well as a building - represents the last chance not only for social exchanges, but also for the promotion of substantial equality. This does not necessarily manifest itself in practice, and we know very well that the income and cultural conditions of families are the variable that most influences actual school achievements and academic paths. Online education, however, opens up a new technology and infrastructure gap that is rooted in social, territorial and economic divides.

Compensatory and support measures have been introduced in all countries, including Italy, for: (i) income (transfers, unemployment benefits, special payments), (ii) companies (transfers again, tax relief, guaranteed loans, possible equity participation), (iii) rent, mainly by means of odious transfers, with people's rents basically paid for by the State for a period, as well as bank credits, also guaranteed by the State. 
In the end, almost a year after the outbreak of COVID-19, countries are implementing packages of measures that are not always coherent, designed and assembled by a plethora of bureaucrats representing conflicting interests (with the bankers, of course, much better represented than the unemployed or street vendors).

The social outcome varies from very limited or no protection for informal sector workers and the unemployed poor (with an even worse situation for immigrants), limited protection for permanent workers and small businesses, greater protection for large non-financial companies (just think of the multi-million euro guarantees requested by large European companies), up to an almost complete parachute for financial and real estate income.

\section{And what about civil liberties?}

Efforts to contain and suppress contagion inevitably involve suggestions or coercive measures. According to the Constitution, freedom and health are two fundamental rights and, of course, restrictions of the former must be strictly proportionate to very urgent needs affecting the latter.

On the contrary, it seems there has been a dangerous convergence between total organizational incompetence (where are the masks produced? who sells us the reagents? and the respirators? and how can we expand the intensive care units?) and a kind of common feeling amplified by collective panic that could be called "medical-ethical authoritarianism".

With all this, the authorities - notoriously incompetent in matters of epidemiology but supported by purported "experts" who, while they did not appear out of nowhere, clearly did not descend from the Olympus of science - regulate our daily lives.

This is a strange and inexplicable ideological coalition between an economic establishment historically indifferent to personal freedoms ("you can only leave the house to go to work") and a kind of ethical pseudo-left ("we are acting in your interests, so shut up and obey"). And so the paradox is that the standard-bearers of demands for State interference to be constrained have become far-right groups, people who are anti-science and conspiracy theorists.

This gives rise to a very serious problem. The models for curbing the pandemic based on social control, which new surveillance technologies make very easy (and against which liberal democracies have very few antibodies, because they have been weakened by the silent, omnipresent intrusion of major digital platforms), are becoming natural and socially acceptable.

\section{Policies and a possible historical crossroads}

The experience of the pandemic teaches some obvious lessons about the policies that should be adopted. ${ }^{3}$

The first very obvious learning is the need to revitalize and strengthen universal public health systems, which have ruined by the "diet" to which the public sector in general -and health in particular have been subjected in the name of a devastating liberalism taken so far that it has undermined such universal rights as health, education and the generation of knowledge. The fight against the pandemic has been called a "war". Indeed: wars have always been too serious a matter to leave to the market.

Second, an important corollary to this point is that the State must regain the ability to plan the production of essential goods and services. A couple of months after the attack on Pearl Harbor, the United States was able to produce one battle tank about every hour. Two months into the pandemic, the

\footnotetext{
3 For a more detailed analysis, see Pianta (2020).
} 
public administration in most countries within and outside the Organization for Economic Cooperation and Development (OECD) was still not able to produce masks, and did not even know exactly who could make them.

Third, the pandemic has highlighted the dramatic inefficiency of a system of medical and pharmaceutical knowledge generation in which most of the cost is borne by the public sector while the private sector is rewarded with overseeing the exploitation of that knowledge and the revenues it earns. As argued in Cimoli and others (2014), there is an urgent need for the public sector to develop autonomous competence over medicines and vaccines up to the human testing stage and, as a result, for a drastic reduction in the ability of pharmaceutical companies to appropriate the huge revenues guaranteed by "intellectual property rights".

However, there are policies and programmes whose urgency has only been accentuated by the pandemic, but which still obey the long-term trends described above.

A year ago (Dosi and Virgillito, 2019), attention was dramatically focused on two archetypes in the crossroads that all societies are facing or about to face: the choice between a form of socioeconomic organization that, following Freeman (1992), could be called the "economy of hope" and another that, in honour of the eponymous film, was dubbed the "Blade Runner society".

Within the political debate, there is finally a growing recognition that something needs to be done in the face of sharply rising inequality, potential mass unemployment, deteriorating working conditions and the erosion of the welfare state. However, the discussions tend to be one-sided (focused on tackling one problem at a time) and too often they are rooted in the interpretative paradigm of economic orthodoxy - based on the idea that policies, if really necessary, should be justified by "market frictions", rigidities or, at worst, "market failures" - on the assumption that, left to their own devices, markets can generally take care of themselves quite efficiently and, consequently, take care of us all. Thus, for example, by definition, long-term technological unemployment cannot exist.

Of course, societies must assess the effectiveness and possible trade-offs involved in different sets of policies - for redistribution, taxation in a globalized and digitized world, education, training, employment, innovation and industry, for example- but they must be considered together.

More importantly, the debate must be placed in the broader context of the new relationships between people and work and between people and institutions. Different policies will lead to different configurations of the State and its intermediate institutions, with different structures ranging from "minimalist States" to "nanny States" and based on various combinations between individual and collective forms of action and between the provision of collective services by the public sector or by the market.

The different combinations have clearly different consequences: not only in terms of income growth, but also, and at least as importantly, as regards social inclusion and the distribution of work, of income and, ultimately, of power.

First of all, for the first time since the beginning of the twentieth century, a under-proletariat (a lumpenproletariat, as Marx would say) is re-emerging in the industrialized countries of today's West, made up of people who cannot work, precarious and often clandestine workers, many "platform" workers, in many ways "non-citizens": think back to the difficulties Italy's homeless encountered and still face in receiving subsidies or access to the social protection system. Until recently, to read Balzac or Dickens was to read historical novels; today they have to be reread as current events.

And this is a growing part of society that we have to deal with; otherwise, we will be in danger of arriving at the Blade Runner society referred to earlier.

As for "real" workers, so to speak, in the minimalist sense of "those who exist", those with social security coverage and perhaps "indefinite" employment contracts (with the tragic irony inherent in that adjective after the reforms, in Italy and elsewhere, to make labour markets more flexible): what can we do? 
Certainly, alternative programmes for labour market institutions include mechanisms for joint decision-making, through which workers exercise some control over company strategies and, as regards earnings, a universal basic income and a minimum wage are urgently called for. Each alternative has, of course, very different distributive and social consequences. For example, micro-institutional engineering measures involving worker co-ownership, profit-sharing or even German-style joint decision-making put the burden of redistribution on the employer or the individual company. While they are likely to be quite effective "locally", the major risk they entail is that of creating a gap between an elite group of workers and the rest. While they have the advantage of increasing the share of wages in the income generated and redistributing productivity gains within the company, they have the disadvantage of exacerbating disparities between groups of workers and are relatively ineffective in addressing overall unemployment.

Instead, the lower end of the income distribution must be addressed through more universal programmes, such as the various forms of basic income. These, however, are not without their limitations. While they provide a safety net for all citizens, their implementation tends to be - at bestneutral in terms of general income redistribution. Indeed, basic income is often accompanied by a vast reduction in the welfare state, which entails the transformation of public goods, such as health and education, into (private) income transfers. It should be recalled that Milton Friedman was one of the first proponents of a universal negative income tax. Moreover, basic income programmes can be subject to political distortions, as the right to their access can be made dependent on citizenship, which raises fundamental questions of discriminatory treatment towards "non-citizens" as a whole. Increasing the minimum income level could also help to establish a minimum threshold for labour participation, which is in free fall. However, one should be careful not to weaken the bargaining power of trade unions and threaten the collective organization of workers. It cannot be the only redistributive measure.

In this regard, taxes must once again be given a leading role. Both innovative and proven forms of progressive taxation should be applied. Particular attention should be paid to understanding both the dynamics of the tax base and the ways in which different types of income, whether profits or wages, and rent (financial and non-financial) should be taxed. The pro-market fury of recent decades has combined with a collective anti-tax ideology that has greatly reduced the redistributive impact of fiscal policies and universal services provision. This trend must be reversed and new combinations of tax rates found, so that rent and wealth in general are taxed more heavily than profits and profits more heavily than wages. It is true that it is becoming increasingly difficult to impose levies on rent and profits, not only because there is no political will to do so, but also because of their characteristics and apparent lack of geographical domicile. The technical means exist, however, as profits and financial flows in general can be monitored from their country of origin to their destination country, usually a tax haven.

At the same time, the targets of taxation can also change. New forms of taxation should at least be discussed, including the "robot tax", the "bit tax" and the "web tax". Some scholars suggest that whoever owns the robots rules the world (Freeman, 2015).

The Republic of Korea has recently introduced a tax on robots, and the possibility is also being discussed in the European Parliament. However, while a tax on robots would likely delay the adoption of technologies that replace human labour, it is not yet clear whether it should apply to robot ownership or to their use. Indeed, it seems much more reasonable to tax the owners (and thereby, ultimately, the profits generated by the robots). In other times, the choice would have been between taxing locomotives or taxing railroad tycoons, to which the answer is obvious. In addition, robots can be used in different ways, many of which are not intended to replace human activities but to integrate them into a wide range of sectors, from agriculture to industry and the service sector (examples include medical and bio-robot applications).

Another proposal, the "bit tax", has been part of the political discourse since the early 1990s (Soete and Kamp, 1996). As transactions and the revenues they produce become increasingly "intangible", the tax base should shift from physical to digital units (i.e. bits of transmitted information). The web tax, 
which is levied on digital transactions, can be considered a form of bit tax. The taxation of platforms is another open question of great importance. Platforms are increasingly using individual resources (such as apartments in the case of Airbnb) to make business profits. These assets, which are widely distributed, generate profits that, in contrast, are highly centralized.

In addition to income policies, attention must also be paid to employment policies. Some are indirect and influence, first of all, the characteristics of the job supply. Policies for education and training fall into this category, as do what are known as "active" labour market policies, which provide training programmes for the unemployed and continuing training for workers, so that they can also overcome the possible obsolescence of their skills. While they are certainly essential, these policies alone are completely insufficient and must be accompanied by more direct policies (Dosi and others, 2019). Companies cannot expect the employees they hire to be trained on an ad hoc basis; instead, they should be encouraged to invest in improving employee learning, particularly through on-the-job training programmes. To cope with rapid technological advances, workers should first and foremost possess a wide range of non-specific skills. In particular, higher levels of reasoning and abstract skills should be taught and developed: in other words, the opposite of what many companies require of new hires.

According to an approach dating back at least to Roosevelt's New Deal, the State is the employer of last resort. Contrary to any notion of a "minimalist State", this vision implies the creation of massive work programmes during times of recession, which offers the double advantage that publicly useful jobs are performed and that people receive an income (Minsky, 1986).

Last but not least, employment policies include the reduction of working hours. This has also been an ongoing trend in industrialized countries since the mid-nineteenth century, in parallel with the symmetrical ongoing trend towards the mechanization and automation of production. Those policies have recently been tried out in some advanced economies with the dual objective of creating new job opportunities and redistributing productivity gains. Certainly, such measures must be accompanied by strong regulatory limits on involuntary part-time work, non-standard forms of work and "mini-jobs".

The State has always been a creator of investment opportunities, a sponsor of risky programmes and long-term research, and a generator of innovations with a concrete mission (Mazzucato, 2013). While this has historically been the case - particularly in military and space programmes - it has also played a crucial role in the development of electronics, computing, telecommunications and, before that, synthetic chemistry and pharmaceuticals.

That historic role should be readopted at the present time. One basic objective should be the introduction of ambitious policies that promote the creation and development of new technological paradigms with the sole imperatives of environmental and social sustainability and a fairer redistribution of labour, income and, ultimately, power.

In this way, the public sector must recover its capacity not only to regulate, but also to shape the very strategies of private agents.

Dosi and Virgillito (2019) highlight the way in which information-intensive activities lead to dramatic "increasing returns" - as economists say - to information itself. This, in turn, tends to lead to a (quasi) monopolistic supply structure: the cases of Google, Amazon, Facebook, Airbnb and Uber are archetypical. How should we deal with the socioeconomic consequences of these trends? Competition policies are one obvious measure, and the European Union has recently started to implement them. Will they be enough? Probably not. History teaches us that when "natural" monopolies emerge, the State must regulate them stringently and comprehensively and give due consideration to their nationalization. In the past, that occurred with telecommunications and other public services. We should not try to avoid such policies today, as we face the strongest drive towards monopolization seen since the dawn of capitalism. 
Today we stand at a historical crossroads, in terms of both technological trajectories and models of socioeconomic organization. We can move towards a form of techno-feudalism with a deeply divided society or towards a society that collectively shares the benefits of technological advances, as Keynes (1931) advocated almost a century ago.

The path we follow will depend largely on the type of policy we design and implement.

At the end of the day, the pandemic is ultimately nothing more than an acceleration factor and, in the author's opinion, not for the better. Emergencies and fear almost always favour authoritarian solutions and the current situation is no exception. More importantly, there seems to be -at least in early October 2020, as this short essay is being written - no perception of the seriousness of the interaction between a profoundly unfair distribution of income and living conditions and measures that restrict social and individual freedoms, which in the long run are incommensurable and exacerbate the very inequalities of living conditions.

To illustrate this in a dramatic fashion, I conclude with a question: if in Germany in 1933, after a series of restrictive policies that brought the unemployment rate to about $20 \%$, Brüning had also introduced lockdown measures, raising unemployment by another $10 \%$, even if it were motivated by the arrival of the Black Death, how many votes does the reader think Hitler would have obtained? The answer is easy: maybe $80 \%$.

\section{Bibliography}

Bellomo, N. and others (2020), "A multi-scale model of virus pandemic: heterogeneous interactive entities in a globally connected world", Mathematical Models and Methods in Applied Sciences, vol. 2.

Cimoli, M. and others (eds.) (2014), Intellectual Property Rights: Legal and Economic Challenges for Development, Oxford, Oxford University Press.

Dosi, G. (1984), "Technology and conditions of macroeconomic development", Design, Innovation and Long Cycles in Economic Development, C. Freeman (ed.), London, Design Research Publications.

Dosi, G. and others (2020), "Costi e limiti della precauzione suggerita da un discutibile report scientifico", Scienza in Rete, May.

Dosi, G. and others (2019), "What if supply-side policies are not enough? The perverse interaction of flexibility and austerity", Journal of Economic Behavior \& Organization, vol. 162.

Dosi, G. and M.E. Virgillito (2020a), "Tutti uguali davanti alla Pandemia?", Scienza in Rete, March. (2020b), "Covid-19: distanziamento sociale e diritti", Scienza in Rete, March. (2019), "Whither the evolution of the contemporary social fabric? New technologies and old socio-economic trends", International Labour Review, vol. 158, No. 4.

Freeman, C. (1992), The Economics of Hope: Essays on Technical Change, Economic Growth, and the Environment, Hardcover, September.

Freeman, C. and L. Soete (1994), Work for All or Mass Unemployment: Computerised Technical Change in the Twenty-First Century, London, Pinter.

Freeman, R. (2015), "Who owns the Robots Rules the World", IZA World of Labor, No. 5.

Keynes, J.M. (1931), "Economic possibilities for our grandchildren”, Essays in Persuasion, J.M. Keynes (ed.), London, Macmillan.

Mazzucato, M. (2013), The Entrepreneurial State: Debunking Public vs. Private Sector Myths, London, Anthem Press.

Minsky, H.P. (1986), Stabilizing an Unstable Economy: The Lessons for Industry, Finance and Government, New Haven, Yale University Press.

Pianta, M. (2020), "L'intervento pubblico dopo l'epidemia: progetti, strumenti, conflitti", unpublished.

Soete, L. and K. Kamp (1996), "The 'Bit Tax': the case for further research", Science and Public Policy, vol. 23, No. 6.

Stiglitz, J. E. (2002), Globalization and its Discontents, New York, W.W. Norton. 